\title{
Digital Tools of Territorial Communities in Improving the Quality of Services to the Population
}

\author{
SIERHIEI SAHANENKO ${ }^{1}$, MYKOLA POPOV ${ }^{2}$, OLESIA HOLYNSKA ${ }^{3}$, NATALIA KOLISNICHENKO ${ }^{4}$, \\ STEPAN DAVTIAN ${ }^{5}$, DMYTRO MOTYHIN ${ }^{6}$ \\ ${ }^{1}$ Odessa Regional Institute for Public Administration, NATIONAL ACADEMYFOR PUBLIC ADMINISTRATION \\ UNDER THE PRESIDENT OF UKRAINE, UKRAINE, E-mail: lana.bond@ukr.net \\ ORCID: http://orcid.org/0000-0002-4816-4579 \\ ${ }^{2}$ Odessa Regional Institute for Public Administration, NATIONAL ACADEMYFOR PUBLIC ADMINISTRATION \\ UNDER THE PRESIDENT OF UKRAINE, UKRAINE, E-mail: popovmykola67@gmail.com, \\ ORCID: http://orcid.org/0000-0002-4816-4579 \\ ${ }^{3}$ Odessa Regional Institute for Public Administration, NATIONAL ACADEMYFOR PUBLIC ADMINISTRATION \\ UNDER THE PRESIDENT OF UKRAINE, UKRAINE, E-mail: a2003710506@gmail.com \\ ORCID: http://orcid.org/0000-0002-4816-4579 \\ ${ }^{4}$ Odessa Regional Institute for Public Administration, NATIONAL ACADEMYFOR PUBLIC ADMINISTRATION \\ UNDER THE PRESIDENT OF UKRAINE, UKRAINE, E-mail: ird@ukr.net, \\ ORCID: http://orcid.org/0000-0002-4816-4579 \\ ${ }^{5}$ Odessa Regional Institute for Public Administration, NATIONAL ACADEMYFOR PUBLIC ADMINISTRATION \\ UNDER THE PRESIDENT OF UKRAINE, UKRAINE, E-mail: st.davtian54@gmail.com, \\ ORCID: http://orcid.org/0000-0002-4816-4579 \\ ${ }^{6}$ Odessa Research Expert-FORENSIC CENTER OF THE MINISTRY OF INTERNAL AFFAIRS OF UKRAINE, UKRAINE, \\ E-mail: ondekc2016@gmail.com, ORCID: http://orcid.org/0000-0002-4816-4579
}

\begin{abstract}
The article considers the main aspects of the introduction of digital tools of local communities and their role in improving the quality of services to the population.

The purpose of the study is an analysis of the ways and scope of use of digital tools by the United Territorial Communities (UTC) in it's activities, in particular to: involve residents in decision-making processes in these communities and improve the quality of services to the population - as a result of UTC cooperation through digital communications. The study focuses on interaction with residents of relevant UTCs, and on the cooperation of local communities in improving the quality of services to the population. Peculiarities and main aspects of digital interaction with the residents of the territorial community and effective coverage of the government's activities with digital tools are identified. It is proposed as a mechanism of cooperation of UTC by means of digital communications to improve the quality of services to the population of territorial communities implementation of the digital communication strategy.
\end{abstract}

Keywords: Territorial and administrative system; Reforms; Digital tools; Territorial communities; Quality of public services; Digital communications strategy.

JEL classification: M15, O18, R12 


\title{
Herramientas Digitales de las Comunidades Territoriales para Mejorar la Calidad de los Servicios a la Población
}

\author{
SIERHIEI SAHANENKO ${ }^{1}$, MYKOLA POPOV ${ }^{2}$, OLESIA HOLYNSKA ${ }^{3}$, NATALIA KOLISNICHENKO ${ }^{4}$, \\ STEPAN DAVTIAN ${ }^{5}$, DMYTRO MOTYHIN ${ }^{6}$ \\ ${ }^{1}$ Odessa Regional Institute for Public Administration, NATIONAL ACADEMYFOR PUBLIC ADMINISTRATION \\ UNDER THE PRESIDENT OF UKRAINE, UKRAINE, E-mail: lana.bond@ukr.net \\ ORCID: http://orcid.org/0000-0002-4816-4579 \\ ${ }^{2}$ Odessa Regional Institute for Public Administration, NATIONAL ACADEMYFOR PUBLIC ADMINISTRATION \\ UNDER THE PRESIDENT OF UKRAINE, UKRAINE, E-mail: popovmykola67@gmail.com, \\ ORCID: http://orcid.org/0000-0002-4816-4579 \\ ${ }^{3}$ Odessa Regional Institute for Public Administration, NATIONAL ACADEMYFOR PUBLIC ADMINISTRATION \\ UNDER THE PRESIDENT OF UKRAINE, UKRAINE, E-mail: a2003710506@gmail.com \\ ORCID: http://orcid.org/0000-0002-4816-4579 \\ ${ }^{4}$ Odessa Regional Institute for Public Administration, NATIONAL ACADEMYFOR PUBLIC ADMINISTRATION \\ UNDER THE PRESIDENT OF UKRAINE, UKRAINE, E-mail: ird@ukr.net, \\ ORCID: http://orcid.org/0000-0002-4816-4579 \\ ${ }^{5}$ Odessa Regional Institute for Public Administration, NATIONAL ACADEMYFOR PUBLIC ADMINISTRATION \\ UNDER THE PRESIDENT OF UKRAINE, UKRAINE, E-mail: st.davtian54@gmail.com, \\ ORCID: http://orcid.org/0000-0002-4816-4579 \\ ${ }^{6}$ Odessa Research Expert-FORENSIC CENTER OF THE MINISTRY OF INTERNAL AFFAIRS OF UKRAINE, UKRAINE, \\ E-mail: ondekc2016@gmail.com, ORCID: http://orcid.org/0000-0002-4816-4579
}

\begin{abstract}
RESUMEN
El artículo considera los principales aspectos de la introducción de herramientas digitales de las comunidades locales y su papel en la mejora de la calidad de los servicios a la población.

El propósito del estudio es un análisis de las formas y el alcance del uso de las herramientas digitales por parte de las Comunidades Territoriales Unidas (CTU) en sus actividades, en particular para: involucrar a los residentes en los procesos de toma de decisiones en estas comunidades y mejorar la calidad de los servicios a la población - como resultado de la cooperación de las CTU a través de las comunicaciones digitales. El estudio se centra en la interacción con los residentes de las UTC pertinentes y en la cooperación de las comunidades locales para mejorar la calidad de los servicios a la población. Se identifican las peculiaridades y los principales aspectos de la interacción digital con los residentes de la comunidad territorial y la cobertura efectiva de las actividades del gobierno con herramientas digitales. Se propone como mecanismo de cooperación de UTC por medio de las comunicaciones digitales para mejorar la calidad de los servicios a la población de las comunidades territoriales la implementación de la estrategia de comunicación digital.
\end{abstract}

Palabras claves: Sistema territorial y administrative; Reformas; Herramientas digitales; Comunidades territoriales; Calidad de los servicios públicos; Estrategia de comunicación digital.

Clasificación JEL: M15, O18, R12

Recibido: 09 de abril de 2021

Aceptado: 12 de junio de 2021 


\section{Introduction}

\section{Relevance of the topic and problem statement}

Modern information technologies expand opportunities in access to information, development of personal competencies, networking and communication, which is especially important for successful decentralization reform. Digitization provides authorities with speed and efficiency in decision-making and improves service delivery to citizens. Digital communications are conducive adaptation of traditional formats to new realities, electronic channels and social networks today have actually become the default choice (Babenko, 2017; Bondarenko et al., 2021).

The main strategic task of modernization of public administration (Al-Ruithe, et al., 2018) and territorial organization of government is the formation of effective local government, creating comfortable living conditions for citizens, providing quality and affordable public services. To achieve these goals, starting from 2014, the Concept of reforming local self-government and territorial organization of power in Ukraine is being implemented (Order № 333-r of April 1, 2014).

Digitization of public administration reflects the process of implementation by the authorities of innovative digital decisions in the social, economic and political spheres and ways to transform them in the decision-making process (Weerakkody, et al., 2016; Omar, et al., 2017). Work on the digital transformation of territorial communities continues in two key components: the development of eservices and e-democracy both at the national level and in the regions of Ukraine (or at the community level). Active implementation of Digital communications in government helps optimize workflows and saves time. Transforming communication processes will help minimize corruption risks and increase the accountability of government (Bondarenko, et al., 2021; Khomutenko, et al., 2019). Such work includes optimization of business processes, formation of strategies and improvement of legislation; development of software, online platforms and services; increasing the digital literacy of civil servants and the population, promoting electronic tools among potential users (Bondarenko, et al., 2019; Florax \& Plane, 2004; Peter \& Robinson, 2014).

The purpose of the study is an analysis of the ways and scope of use of digital tools by the United Territorial Communities (UTC) in its activities, in particular to: (1) involve residents in decision-making processes in these communities and (2) improve the quality of public services - as a result of cooperation UTC by means of digital communications.

In the framework of this study, the following problematic issues are identified:

- identify the features and main aspects of digital interaction with the residents of the territorial community and effective coverage of the activities of the authorities with digital tools;

- to develop a mechanism of UTC cooperation by means of digital communications to improve the quality of services to the population of territorial communities.

Research hypotheses:

H 1. UTC 's capacity to integrate into the European digital infrastructure is determined by the level of dissemination and current practice of using digital tools to interact with OTG residents.

H 2. UTC cooperation, based on which tools and means of digital communications contribute to improving the quality of services to the population of local communities.

\section{Literary review}

The reform of the territorial and administrative system in Ukraine based on decentralization, ie the transfer of powers and budget revenues from state bodies to local governments (OECD, 2016).

The reform aims to give local communities the opportunity to manage greater resources and mobilize their internal reserves (Regions Matter, 2009). As a result of the reform of local selfgovernment bodies, the association (consolidation) of territorial communities (UTC) has envisaged (Charter, 2014). This will reduce the cost of maintaining the management staff, will allow the redirection of resources for the implementation of local development projects (Eising, 2004). 
With this approach to the consolidation of the territory of communities, a prerequisite is to improve the living conditions of the community (Rabinovych, et al., 2018).

The introduction of the principle of subsidiarity contributes to the creation of a modern municipal government, in accordance with the principles and spirit of the European Charter of Local SelfGovernment (Umland, 2019).

However, in the process of comprehensive public administration reform, there are still serious limitations in opportunities at all levels of government in Ukraine. Many regional and local authorities lack the knowledge and understanding to cope with the expanded responsibilities, some of which are unable to take advantage of the new opportunities (Podgorna, et al., 2020, Gontareva et al., 2020).

The newly formed communities face numerous legal, financial and managerial challenges. Special attention needs to be paid to the creation of digital communications to solve problems of cooperation at all levels, both horizontally and vertically of public administration (Tkach, et al., 2019).

After all, the structure of the administration of the territorial community is changing, a new institution of the territorial community is being created - the headman.

A number of important services have transferred to the centers of affluent communities from the district centers - administrative, social assistance through territorial centers, fire, law enforcement, sanitary-epidemiological service, etc. Executive bodies of district and oblast councils are being created, which significantly strengthens local self-government, makes the system of power in the regions truly democratic - the regions will be governed by entities elected during local elections (OECD, 2018).

Ukraine is implementing the Government Program for Government Accountability and Community Participation (EGAP Program) (2015-2023) by the Eastern Europe Foundation and the Innovabridge Foundation in partnership with the Ministry of Digital Transformation of Ukraine. This program is implemented with the support of Switzerland, provided through the Swiss Agency for Development and Cooperation (SDC). The target regions are Vinnytsia, Volyn, Dnipropetrovsk, Luhansk and Odessa regions of Ukraine.

For the development of electronic services in Ukraine, the Electronic Democracy Platform E-DEM (e-dem.ua) was created, which brought together the most popular among thousands of users electronic services (in particular - a single system of local e-petitions petition.e-dem.ua, platforms "Open City" opencity.e-dem.ua and voting for the participation budget budget.e-dem.ua), a new service for local authorities - electronic consultations consult.e-dem.ua.

The introduction of digital tools and communication mechanisms will help make public services convenient, high quality and transparent, and people will have the opportunity to improve the quality of life in their communities (Sagan, et al., 2020; Sudomyr, et al., 2020). Thus, the electronic service "Public Consultation" allows the local government to involve residents of the community in surveys, evaluation of decisions or voting.

According to Concepts of e-democracy development in Ukraine, approved by the Order of the Cabinet of Ministers of Ukraine 797-r of November 8, 2017, e-democracy is a form of public relations in which citizens and organizations have involved in state formation and public administration, as well as local self-government. The introduction of e-democracy has carried out through the widespread use of information and communication technologies in democratic processes, which allows:

- to strengthen the participation, initiative and involvement of citizens at the national, regional and local levels in public life;

- improve the transparency of the decision-making process, as well as the accountability of democratic institutions;

- to improve the response of the subjects of power to the appeals of citizens; facilitate public discussions and draw citizens' attention to the decision-making process.

That is, e-democracy is based on the use of modern available digital technologies. Thanks to edemocracy tools, citizens will be able to influence government decision-making and increase their influence on politics at both the national and local levels (Rodriguez-Pose \& Garcilazo, 2013). 
The EU pays considerable attention to the compliance of the level of local self-government with the basic standards of the European Regional. International technical assistance projects, with a total budget of more than $\$ 403$ million (Projects and programs), have paid significant attention to the digital side of UTC 's activities.

Thus, the important question is how effectively UTCs use their potential of digital management technologies in terms of the transition from paper to digital format. The Law of Ukraine "On Access to Public Information" defines the procedure for access to information on the official websites of local governments. Resolution № 835 of 21.10 .2015 approved the Regulations on data sets that are subject to disclosure in the form of open data and a number of other regulations that oblige local governments to disclose certain documents.

Conceptually, the digitalization of UTC activities in the early stages of development has characterized by the introduction of digital tools, without a long tradition of working with previous generation systems. That is, as the experience of Ukraine shows, it is necessary to implement innovative systems, because in our country these systems have created from scratch, and do not replace the previous solution. Such implementations are individual in nature, depending on the digital readiness (maturity) of the community, which is determined by a combination of UTC factors and the characteristics of the local governments.

\section{Methodology}

The study involves the use of tools:

- content analysis of UTC web pages, Fb-pages and Fb-groups of UTC, UTC pages on social networks Twitter, Instagram and YouTube;

- semi-structured interviews with management representatives of those UTCs that were included in the site analysis to supplement the quantitative analysis data.

The theoretical basis of the study is the classification of e-government (Margetts, 2007), when egovernment has considered in terms of three components:

(1) the internal system of work;

(2) the interface of interaction with the "client";

(3) the method of communication with other organizations.

The study focuses on the second component - interaction with the residents of the respective UTCs, and on the third - the cooperation of local communities in improving the quality of services to the population. Through the prism of the principles of "digital default", "accessibility and involvement of citizens", "openness and transparency", "trust and security" mentioned in the documents of the European Commission and the Cabinet of Ministers, the channels of communication (website, Fb-page, etc.) were analyzed. Both the benefits of e-government for UTC management and residents of the united communities, and the challenges that arise in the process of systems. Were analysis of web resources 240 UTC (30\% of the total, 2020) (Monitoring of decentralization, 2020).

Communities from the UTC list were selected for the studyregions of Ukraine: Vinnytsia, Volyn, Dnipropetrovsk, Luhansk and Odessa regions. Community websites or a council website, if available, located in the center of that community were considered. If the community had both a community website and a council (a rare phenomenon), the community website was taken into account. A study of the degree of openness to communication of community leaders was conducted (Malyarets et al., 2019). To do this, letters were sent to e-mail addresses from the contacts listed on the website with a request to interview representatives of the UTC management, or to fill in the proposed online questionnaire. Also, as part of the study, a content analysis of UTC residents' communications on public pages on social networks and in relevant local online groups was conducted. We used links from the website or a search tool for social networks (Twitter - links on the UTC website). According to the data, correlation and regression analyzes were performed. The sampling error with a probability of 0.95 does not exceed $5.5 \%$. 


\section{Evaluation and analysis of results}

\subsection{Organizational structure of digitalization during the decentralization reform}

The process of digital transformation is a very important element of the success of decentralization reform and the creation of united territorial communities. Now The Ministry of Finance of Ukraine supports the digital transformation of regions in such areas (Ministry):

- telecommunication and information infrastructure;

- digitization of public services;

- e-democracy tools and their implementation in social spheres;

- organizational and resource support for the development of digitalization;

- information security.

The state policy of regional digitalization has aimed at creating a platform for interaction between cities, towns and villages, government agencies and non-governmental organizations. Digital development is a priority of public policy, because decentralization directly depends on the digital changes taking place in the country. Technology and innovation must serve the people living in communities. That is, the focus shifts to communities that need to actively implement technologies, principles of e-government and e-democracy.

At present, Ukraine has already built an organizational structure in the state power, which allows to accelerate the digitalization of the country. Digitization units should appear in every city and community. A Digital Solutions Marketplace will be launched, bringing together the best digital products for communities with instructions.

Ministry of Statistics of Ukraine launched the portal "Action. Digital Community" with digitization tools for communities. The Cabinet of Ministers of Ukraine has approved the introduction of a new position of head of digital transformation in all public authorities (CDTO). At the level of state bodies it is a profile deputy. Also, the Directorate of Regional Digitization was established under the Ministry of Finance, and the positions of CDTOs - deputies for digital transformation in regional state administrations (RSA) and mayors were introduced.

The Ministry of Finance is preparing a state program "Internet Subvention" in 2021. This will provide access to fixed high-speed Internet 3 thousand villages, which are home to about 1.5 million people. This project will help connect social infrastructure institutions - schools, authorities, libraries, hospitals located in villages where no ISP provides services using fiber-optic technology.

For example, the "Baby" service last year became a pilot project in the Vinnytsia region, and from March 2020 - throughout the region.

One of the examples of effective interaction of territorial communities with other entities in the field of public administration is the Project "E-solutions for communities", which was implemented Innovation Development Centerwith the support of the program "U-LEAD with Europe". The goal is to help communities move to "governance 2.0 " - based on data analysis. The E-Solution project was launched in Ukraine in early 2019. Then almost 300 communities from 23 regions of Ukraine expressed a desire to participate in the curriculum and further implementation of analytical e-services. And only 50 formed UTC development teams from 21 regions of Ukraine were given the opportunity to complete a full training course and receive consulting support from project experts, implement IT tools and begin the transition to Office 2.0. As a result, UAH 2.5 million is a direct economic benefit to communities from the Project. This testifies to the demand and relevance of this project, which is an example of effective public-private partnership and partnership of local communities with commercial structures and public organizations to address important issues of life of local communities and residents of relevant settlements.

Areas for solving the problem of lack and quality of data have implemented by: 
1) development of the cloud database - information from local data from on-site IT systems, cloud IT solutions that are implemented Center for Innovation Development (CRI) in communities, integration into the cloud of relevant open data and government IT systems (Statistics Service, Ministry of Finance, Ministry of Justice);

2) simultaneously with the construction of the data cloud to develop in the cloud a portfolio of the best IT solutions for collective use by communities, which they all need and are both data sources (UTC registers, addresses, assets, budgeting systems, e-queues for educational, medical institutions, registers beneficiaries, citizen cards, e-tickets, e-democracy services, etc);

3 ) through the development of analytical teams in communities, regions and national authorities to develop the demand for analytics (data), which will improve their quality, the emergence of effective models for monitoring, forecasting, solving typical management problems.

Promoting the digital transformation of Ukraine's regions is one of the focuses of the EGAP Program. The program offers numerous solutions for local governments that improve the quality of government, government-community interaction, promote social innovation, and reduce the digital divide at the regional level.

The introduction of digital communications at the level of state regional administrations, local governments and UTCS contributes to:

- increasing the institutional capacity and competencies of local governments;

- activation of civil society and its involvement in communication with the authorities in the decision-making process, including through the tools of e-democracy;

- improving performance Center for Administrative Services (CNAP), in particular - through their automation, staff training and introduction of new e-services;

- development of digital technologies and digital security of the community;

- developing inclusive digital literacy programs for different populations.

During its first phase in 2015-2019, the EGAP Program had the opportunity to pilot certain approaches and new tools (EGAP) at the regional level. In particular, in Vinnytsia, Volyn, Dnipropetrovsk and Odessa regions there were:

- developed and updated regional informatization programs, on the basis of which financial plans for the introduction of information and communication technologies (ICT) were drawn up;

- CNAP automation was carried out and interaction with regional service portals was established;

- training of employees of local CNAPs of stress resistance, customer orientation and competencies of administrators was carried out, as a result of which the level of quality of providing administrative services to citizens increased;

- implemented the project "Mobile CNAP", which simplified the receipt of administrative services by citizens who for one reason or another can not visit the institution;

- introduced service platforms "Designer of UTC sites" and geographic information systems (GIS), which have become useful tools in the work of newly created UTC;

- a number of political dialogues and roundtables were initiated, which improved cooperation between regional and national policy initiatives.

In the second phase of the EGAP Program, which will be implemented during 2019-2023 in five target regions - Vinnytsia, Volyn, Dnipropetrovsk, Luhansk and Odesa oblasts, about forty UTCs selected on a competitive basis will be involved in the digital transformation.

An important component of this work is conducting digital audits and drawing up detailed plans for digital transformation based on them - with their further implementation in cooperation with local authorities and civil society. As a result of the introduction of modern IT, e-government and edemocracy tools, as well as training of local specialists and ordinary residents, transparent and open communication between the government and citizens has established in selected communities, corruption has minimized and people's access to administrative services is facilitated. One of the 
important results of such activities is the emergence of "digital" success stories of communities, which contribute to the involvement of even more regions in the digitization process.

\subsection{Analysis of decentralization reform in Ukraine}

At the beginning of 2020, 1,029 united territorial communities were created in Ukraine, which united 4,698 communities with a population of 11.7 million people.

Dynamics The results of territorial and administrative reform in Ukraine have presented in Table 1.

Table 1. Dynamics of territorial and administrative reform in Ukraine

\begin{tabular}{l|c|c|c|c|c|c}
\hline \multicolumn{1}{c|}{ Indicators } & 2015 & 2016 & 2017 & 2018 & 2019 & $\begin{array}{c}\text { Prospective } \\
\text { plans }\end{array}$ \\
\hline Number of united communities, units & 816 & 1784 & 3180 & 4010 & 4698 & 10075 \\
\hline $\begin{array}{l}\text { The amount of Amalgamated } \\
\text { Territorial Communities (UTCS), units }\end{array}$ & 159 & 366 & 665 & 876 & 1029 & 1441 \\
\hline Area of the country covered by UTCs, $\%$ & 6.6 & 16.0 & 30.0 & 37.0 & 44.2 & 90.3 \\
\hline $\begin{array}{l}\text { Number of residents of UTCs, million } \\
\text { people }\end{array}$ & 1.4 & 3.2 & 5.7 & 9.0 & 11.7 & 39.2 \\
\hline
\end{tabular}

In 2019, 223 were formed united territorial communities, in 2018 - only 141 . That is, the process of decentralization in Ukraine continues, it has believed, the force of resistance, which was formed from the first steps of the reform, is gradually being overcome.

Leaders and outsiders among the regions of Ukraine in terms of the level of formation of united territorial communities have presented in Figure 1.

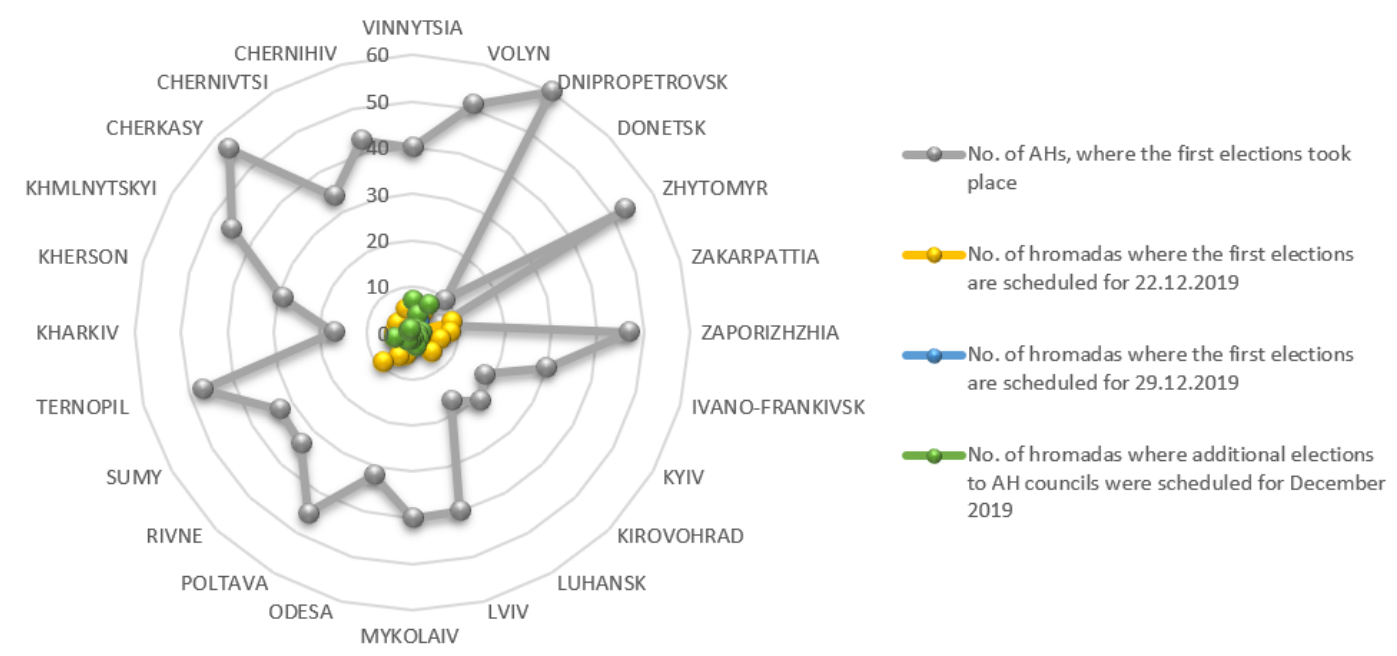

Fig. 1. Regions leaders and outsiders according to the results of UTC formation (2020)

At the beginning of 2019, the rating of oblasts for the formation of affluent communities was headed by Khmelnytsky, Zhytomyr, Chernihiv, Zaporizhia and Volyn regions. At the beginning of 2020 - Zhytomyr, Dnipropetrovsk, Chernihiv, Khmelnytsky and Zaporizhia regions.

The five outsider regions have also not changed significantly. At the beginning of 2019, these were Vinnytsia, Poltava, Kyiv, Kirovohrad and Zakarpattia regions.

At the beginning of 2020 - Kyiv, Lviv, Zakarpattia, Vinnytsia and Kirovohrad regions. Almost $10 \%$ of Ukraine's territory remains without project communities. Odesa and Kyiv regions are still the most problematic, as well as many unresolved issues in Vinnytsia, Cherkasy and Lviv regions.

According to the current long-term plans, in less than a year, the government and local state administrations will need to integrate more than 5,000 villages, settlements and urban communities into the system of united territorial communities of Ukraine. The average number of territorial communities united in united territorial communities, during 2015-2019 are shown in Figure 2a, the average population of one united territorial community - Figure $2 b$. 


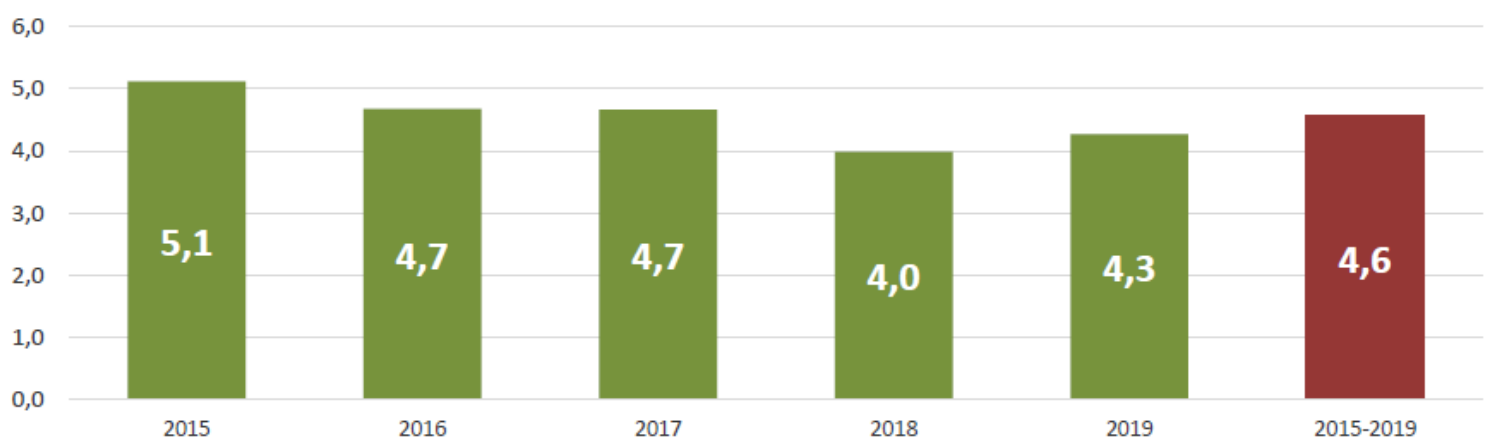

Fig. 2a. Average number of chromads, which amalgamated into one $\mathrm{AH}$

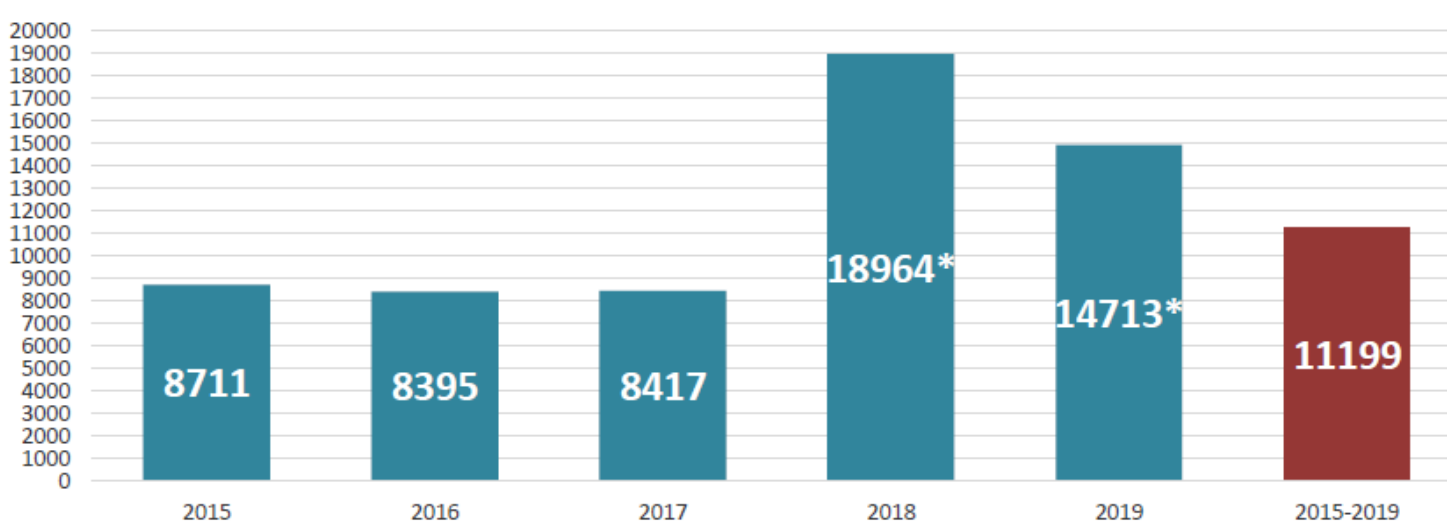

Fig. 2b.Average population of one $\mathrm{AH}$ (persons)

"note: a significant increase due to the accession of the territorial community to cities of regional importance

According to the data, a significant increase in population occurs when a community joins a city of regional significance. In 2019, the process of joining communities to the united territorial communities and cities of regional significance was significantly intensified. More than 100 united territorial communities have already passed the procedure of joining neighboring communities. In total, almost 250 neighboring village and settlement councils joined them. Under a simplified procedure, more than 100 communities joined 44 cities of regional significance.

In 2019, the mechanism was intensified community cooperation. At the beginning of 2019, communities concluded 296 cooperation agreements, and the beginning of 2020 - 530 agreements (+ 234 agreements). The subject of such cooperation agreements are issues of various kinds, the solution of which requires the participation of several territorial communities. For example - garbage collection, utilization and processing, provision of high-quality centralized water supply and sewerage, road repair and cleaning, organization of passenger transportation, fire protection, etc.

It is possible to solve such issues if we cooperate - to unite funds and efforts with neighboring communities, which are also interested in this.

The normative and legal support for the implementation of the mechanism of such inter-municipal consolidation is the Law of Ukraine "On cooperation of territorial communities", which was adopted in 2014. Since then, a number of community issues have been successfully addressed through the conclusion of cooperation agreements, which has significantly improved the quality of services provided in their territory.

In the course of decentralization, affluent communities have been given greater powers, resources and responsibilities. The list of services that can be provided on the ground is constantly expanding. Residents of united communities expect convenient and high-quality administrative services from local authorities. That is why it is important for each united community to decide as soon as possible how to provide these services to residents quickly and affordably. Obviously, united communities must be modern Centers for providing administrative services, where you can get the necessary administrative 
services. As a result of the decentralization reform measures, 775 administrative service centers were established at the beginning of 2019, and 806 such centers (+31) at the beginning of 2020. Experience shows that most of the new centers were opened in united communities.

In 2019, the Association of United Territorial Communities conducted a survey to find out the opinion of the population on the organization of administrative services. The geography of the survey consisted of residents of 37 cities, 60 settlements and 103 villages of Ukraine. The survey involved 200 united territorial communities $-25 \%$ of the total number formed.

As of April 1, 2019, 148 administrative service centers were established in the united territorial communities, 66 (45\%) of which took part in the survey. Almost half of the surveyed united territorial communities provide services through the headman, namely $45 \%$, which indicates the low use of the institution of headmen as an element of the system of providing administrative services at the local level, and this task should be a priority.

A fairly large percentage of the surveyed united territorial communities, namely $40 \%$, provide administrative services through their own structural units, continuing to use the office system and the old organizational processes in servicing the residents of the united territorial communities.

The shares of providing administrative services through own centers of administrative services and centers of providing administrative services of the district state administration are almost equal - $33 \%$ and $30 \%$ respectively, while $16 \%$ of the surveyed united territorial communities do not plan to form their own centers of administrative services.

This indicates the low institutional capacity of such united territorial communities in organizing the provision of administrative services for their residents. The main reasons for not wanting to establish their own administrative service centers among the surveyed united territorial communities are: lack of sufficient funds to open a new administrative service center (40\%), lack of qualified staff $(25 \%)$ and lack of premises (29\%) . $21 \%$ of respondents say that there is no state support in organizing the work of administrative service centers.

The most important services to be provided at the local level are administrative services, the provision of which has long been introduced through administrative service centers, namely residence registration services (94\%) and real estate registration (82\%). It is also important to provide services that are currently provided only singly through administrative service centers, namely social services $(82 \%)$ and land services (73\%).

$93 \%$ of respondents mentioned the need to share experiences in the field of administrative services. It is best to carry out such an exchange through the organization of study trips to the united territorial communities, where the centers of administrative services are already open.

This was stated by almost $70 \%$ of respondents from the united territorial communities, while the effectiveness of conferences on the exchange of experience was noted by only half of the respondents.

The challenge of the reform is the situation with the small population of UTC, but at the same time this fact is an opportunity to successfully establish communication channels between residents and between them, which will contribute to democracy and transparency of decisions.

Only $38 \%$ of the surveyed united territorial communities have experience of cooperation with programs and projects of international technical assistance, of which almost 90 cooperate with the ULEAD program, $11 \%$ with GIZ and $5 \%$ with UNDP. In general, $90 \%$ of respondents are interested in such cooperation.

According to a survey conducted by the International Center for Policy Studies on "Evaluation of Decentralization Reform", the main objectives of decentralization reform were identified. To the question, what do you think should be the ultimate goal of the reform, the largest number of answers were received (Fig. 3): 


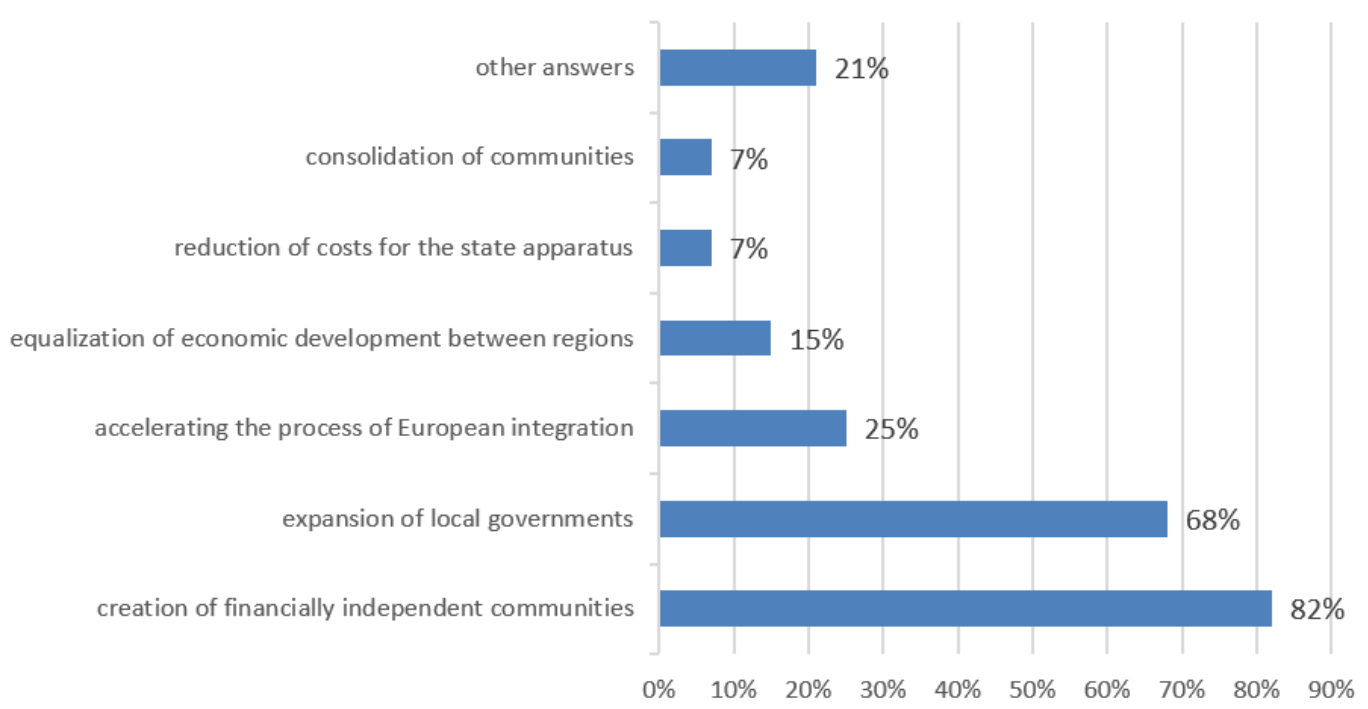

Fig. 3.The main goals of decentralization reform, according to respondents

As can be seen, the creation of financially independent communities is the most perceived ultimate goal of decentralization reform (82\%). Expansion of local governments, their capacity is $68 \%$ of respondents. Respondents believe that this reform is an opportunity to accelerate the process of European integration (25\%), bridge inequality gaps, equalize economic development between regions $-15 \%$.

Experts also identified the main factors that may hinder the implementation of the reform (Fig. 4).

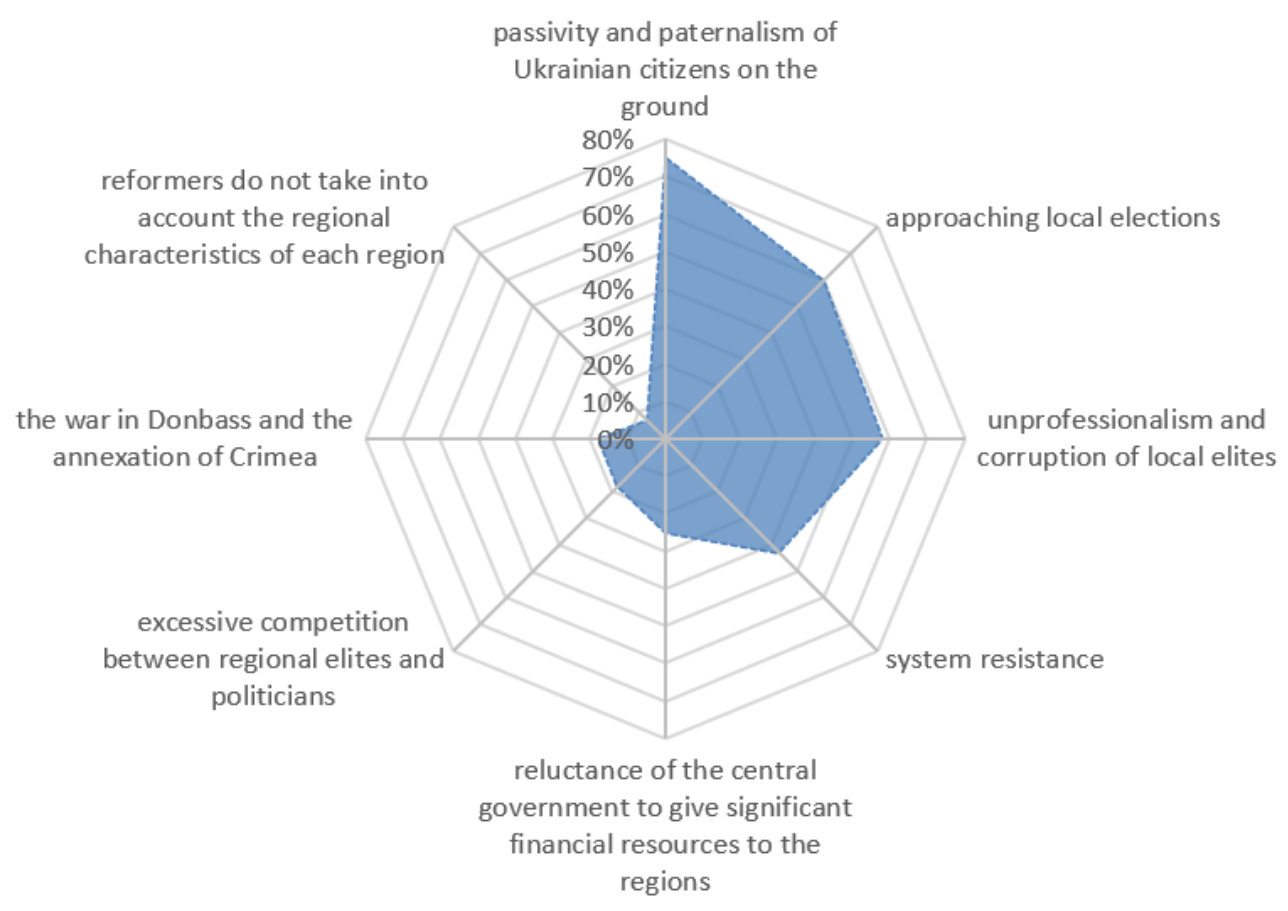

Fig. 4.Factors that may hinder the implementation of decentralization reform, according to respondents

The biggest obstacles are the passivity and paternalism of Ukrainian citizens on the ground (75\%), the approach of local elections (60\%), unprofessionalism and corruption of local elites (58\%), significant natural resistance to change $(43 \%)$, unwillingness of the central government to provide significant financial resources to the regions (25\%), excessive competition between regional elites and politicians and the war in Donbass and the annexation of Crimea - 18\% each. In addition, it is noted 
that in many cases, reformers do not take into account the regional characteristics of each region (7\%).

Thus, the targeted impact on key factors allows in the course of reform to improve exactly those parameters that are most important for attracting the best efforts and resources. This allows us to use the targeted direction of reforming the administrative and territorial system as a mechanism of interaction between the state and local government.

Thus, decentralization has resulted in an improved system of administrative services. However, due to the delay in the reform in some regions of Ukraine, we have significant shortcomings in the implementation of an important task of administrative-territorial reform - the provision of quality administrative services to the population

\subsection{Digital UTC tools}

Long-term plans for community reform include increasing the efficiency of UTCs to use their potential in digital management technologies.

Gaps in the degree of availability of digital technologies and the scale of their use for the regions of Ukraine persist. Typical for Ukraine is the difference in the state of the economy between the center and the periphery. Across the country as a whole, there is a pronounced digital divide between urban and rural areas - approximately $35-40 \%$. Studies show that currently 8.3 million people in Ukraine live in a state of digital inequality. Internet access is available in all cities of Ukraine (in Ukraine, according to the State Statistics Service, as of 2019, there are 461 cities, 886 towns and 23,370 villages). Things are worse in small settlements - only 4,000 villages out of 23,000 have at least one Internet provider. 12.8 million people live in such villages. For comparison: 6.5 million people live in 4,000 villages with an Internet connection. The degree of digitization has influenced by interregional differentiation, which may be different for the center, ie in relation to developed settlements with high incomes, and the periphery - less developed settlements with low incomes. As you can see, the Ukrainian economy has characterized by inequality in the level of average wages and unemployment by region.

According to the Internet Association of Ukraine, the country is experiencing a stabilization of the number of Internet users and, as a consequence, reducing the "digital divide". Starting from 2015, the number of users varies between 21-22 million (shaikh 2019). Taking into account the decrease in the total population of Ukraine, Internet penetration has increased slightly during this period and, as of May 2018, is 64.9\% (the number of Internet users per 100 inhabitants). The total share of Internet users in villages and cities with a population of up to 100,000 increased from 51\% (at the end of the second quarter of 2015) to about 56\% today, and Internet penetration in Ukrainian villages reached $53 \%$. The remaining $44 \%$ of Internet users live in cities with a population of over 100 thousand, penetration there reaches $75 \%$. As already mentioned, feature of the country is a significant generation gap in the context of the intensity of the use of digital technologies. In other words, those Ukrainian families in which the older generation plays an important role do not use Internet services. The share of Internet users over the age of 55 has increased in three years from $12 \%$ to $15 \%$. Penetration in the age category of $55-64$ years now reaches $44 \%, 15 \%$ of Ukrainians over 65 use the Internet. However, numerous observations show that broadband is completely inaccessible to vulnerable social groups, regardless of the city or village. Penetration in the age category of $55-64$ years now reaches $44 \%, 15 \%$ of Ukrainians over 65 use the Internet.

The sample of the study was 240 UTC by region of Ukraine (Vinnytsia, Volyn, Dnipropetrovsk, Luhansk and Odessa regions) by type of community:

- urban - an average population of 23,000 people;

- settlement - population 12,000 people;

- rural - population 4700 people.

The representation of UTC on the Internet is shown in Figure 5. 


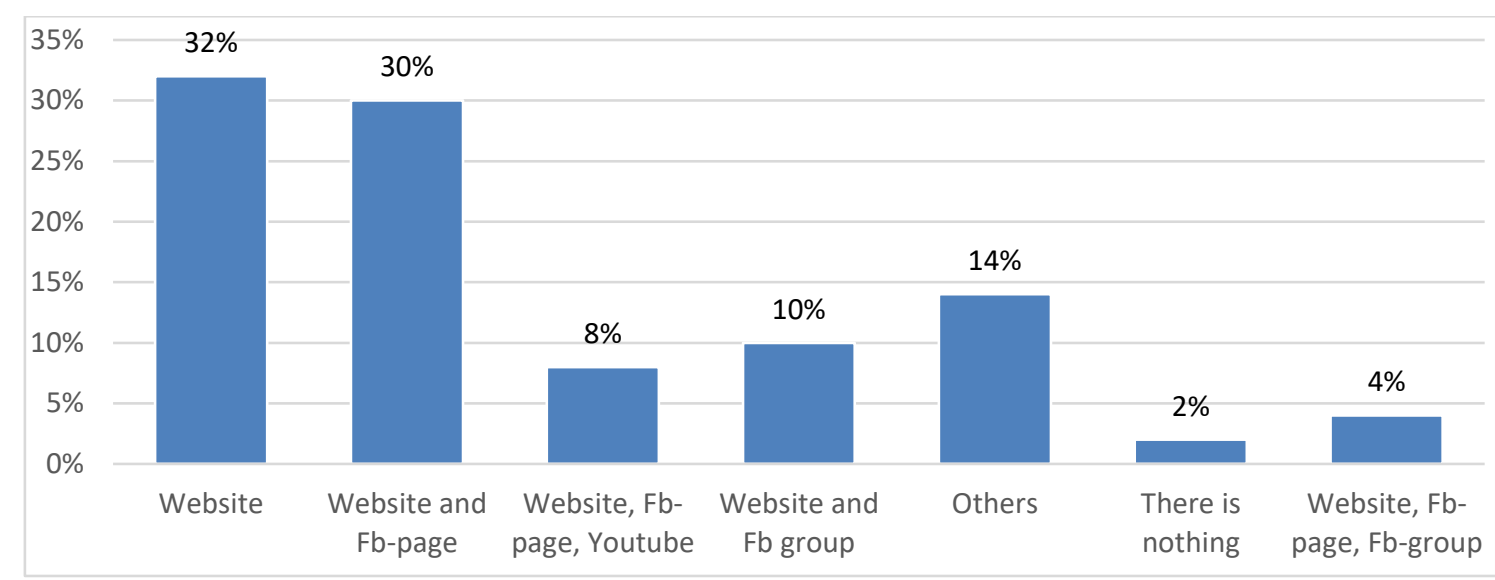

Fig. 5. Representation of OTG on the Internet

As can be seen, more than a third of UTCs have websites, with 95\% of UTCs having their own website and $100 \%$ of urban communities. In some cases, communities did not create a new website and continued to use the council's website, which became the center of the UTC, supplementing the resource with relevant information. There have been cases where communities have purchased a website template and set it up from a commercial company, or become part of an international technical assistance project that created a website for them for free. However, it is still noted that $87 \%$ of communities (5.4\% of UTCs formed after October 2017) still do not have a website. UTCs that were created earlier already have their own websites.

Thus, the analysis shows that the majority of communities show a fairly high online activity, but the cost of developing and maintaining the website itself is not a priority for them. Yes, almost half of those communities that do not have a website have their own Fb page and / or Fb group, sometimes an UTC that does not have a website has its own YouTube channel. That is, these UTCs are present in the online environment, but choose a cheaper (free) channel of communication on the Internet.

According to the results of the interviews with the representatives of the communities, it was established that most UTCs do not have funds for an official who will deal with online tools. In addition, there is a very low level of digital literacy, lack of sufficient skills.

Therefore, the confirmation is the attendance of the community site, ie the relevance and popularity among residents. Thus, $78 \%$ of community websites were visited by a maximum of $25 \%$ of the population during the month. However, it is hardly possible to draw any conclusions from these data, except that in $22 \%$ of cases the website aroused the interest of no more than a quarter of the UTC population. Traffic to community websites varies according to the type of UTC and varies from city to village and from village to village. Thus, the average activity of visiting the city site is 4700 visits per month, village - 840, rural - 510. Traffic to the UTC website is influenced, in particular, by the presence of community profiles on social networks (including YouTube), where links to news from the website are published. There is also a direct dependence of UTC website traffic on the quality and richness of information on community income and expenditure. Community sites receive almost half of the traffic (47\%) from search engines. That is, the website has used by residents mainly to access documents or static information. This indicates the relevance of SEO-optimization for community web resources. $43 \%$ of websites update the news section less than once a week, or do not update at all. Updates depend on UTC 's human and financial resources. The news section is relevant, which makes it possible to publish publicly available information about community activities free of charge. This is especially true in rural communities, where half of the websites (52\%) are passive. That is, there is a direct relationship between the quality of content of sites and pages in social networks and the activity of residents on these resources.

UTC representatives emphasize the advantages of social networks over websites as a means of communication with residents. Yes, $65 \%$ of the sample communities are on Facebook. Of these, $46 \%$ have only a page, $14 \%$ only a group and $4 \%$ both a page and a group. The average page covers $7 \%$ of 
the population, the group - $11 \%$. If we compare $\mathrm{Fb}$-pages and Fb-groups of united communities, in urban UTC comments are left more often on Fb-pages than in Fb-groups. In contrast, rural and urban UTCs have the opposite situation - they comment on Fb-pages more often than Fb-groups. Analysis of the data from the sample found that despite the fact that the Fb-page is the most common option for the presence of an institution or organization on Facebook, better interaction with residents can be obtained in groups. Incidentally, the number of participants in groups is almost twice as large as the number of subscribers per page. As citizens will publish information on UTC activities in these environments, it is important to develop a response scheme for such publications and to identify those responsible for monitoring, collecting and responding to them. It is recommended that key issues be commented on by management, demonstrating their own attention to the event.

$18 \%$ of the sampled communities have a YouTube channel. In urban UTCs this figure is $36 \%$, in urban $-25 \%$, and in rural $-8 \%$. YouTube is a free video hosting that allows you to attract additional visitors. There is an interdependence between the number of views and visits to the site.

Instagram is used by $12 \%$ of urban communities, $7 \%$ of urban UTCs and $3 \%$ of rural ones. The average profile publishes 15 photos per month and has 274 followers, of which about a quarter are "bots" (29\%). About a third of the sample profiles do not receive comments. Instagram is a channel to involve young people in community activities. This involvement generally works, because the growth in the number of published photos has a positive effect on the number of subscribers, ie attention to the channel. In general, communities actively use digital tools to interact with residents.

\subsection{Digital communication strategy}

The digital component promotes active communication in conditions of social distancing.

According to the survey, $79.4 \%$ of UTCs have shown their flexibility and adaptability and switched to an online format of work, using all possible digital tools and applications. Especially in the conditions of a pandemic and restrictions of socialization digital decisions began to be actively implemented. However, as practice shows, in territorial communities due to the lack of communication strategies to implement these tools began chaotically and unreasonably. Each community has its own needs and opportunities, areas of work and target audience (shahzad et al 2019). Therefore, the implementation of digital solutions requires analysis and an individual approach. The best option for the use of digital communication in the community is formed as a result of determining the target audience and choosing the most effective channels of communication with it.

The community site serves as an official source of information and forms a database of the community. The target audience of the site is an active part of the community, namely: politicians, activists, journalists, managers and tourists. It is these categories of people who will use the information from the site the most. The target audience of Facebook includes employed residents over the age of 25. Young people spend more free time on Instagram. Therefore, the public page of the community on Facebook will help to establish communication with a large audience of residents aged $25+$, and Instagram will strengthen communication with active youth aged $13+$.

Messengers are the fastest way to inform residents about community events. But to determine which messenger to use, you need to find out which application is popular in the region (Viber, Telegram or Facebook Messenger). This can be done through a survey of citizens.

Figure 6 shows which tools are best for different target audiences.

The effectiveness of working with digital tools increases if you plan to create content. The use of the content plan in working with the site and social networks will systematize the work and provide quality coverage. By researching the target audience of each of the digital tools that are planned to be used for information, it is possible to achieve quality communication with residents and effective coverage of government activities. The content plan will facilitate and systematize the work of specialists, and the result will be clearly expressed in coverage and feedback. 


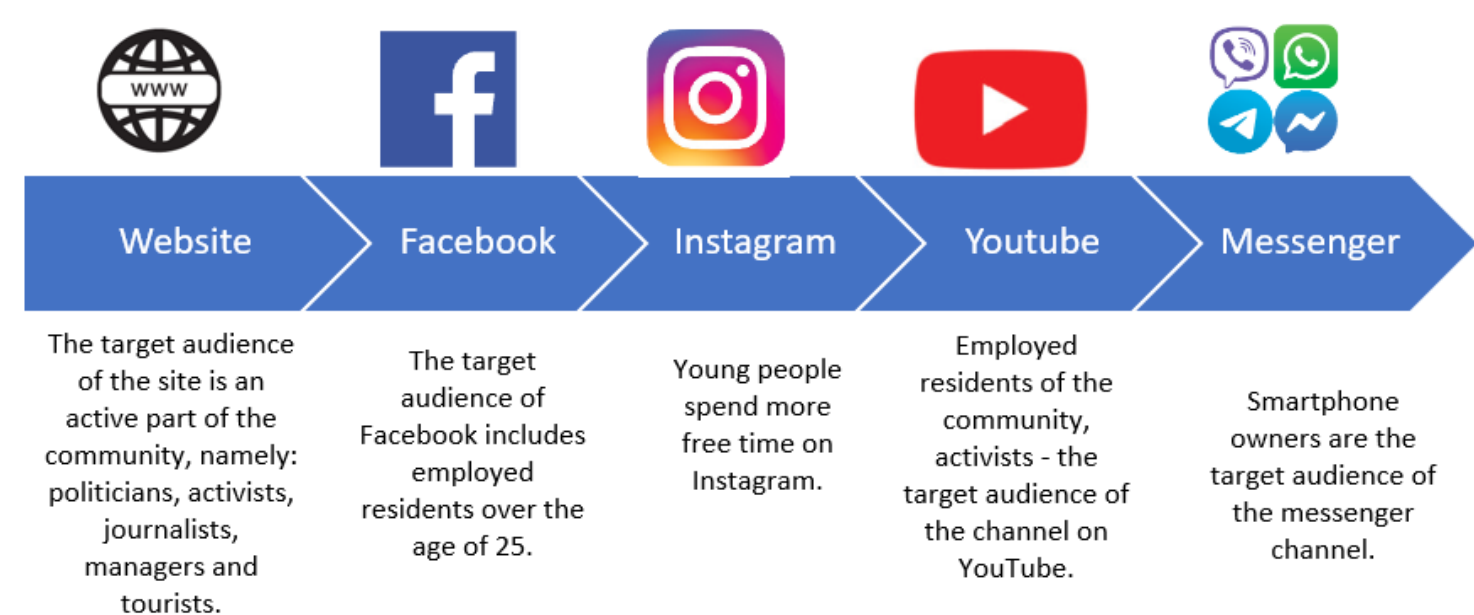

Fig. 6. Digital tools: target audience

Digital communication tools are modern channels of communication with residents, the skillful use of which will build trust between government and the community.

Digital communication strategy is the planning of the most effective use of information and digital technologies in the activities of the organization in order to increase the visibility of the organization, change the behavior and thinking of a specific target audience, solve a problem or bring certain topics to the general public. The essence of the strategy is to effectively solve various problems with the help of various technologies and tools. A systematic approach to the use of digital technologies is an important component of the organization's development strategy. The methodology consists of three main elements (Fig. 7).

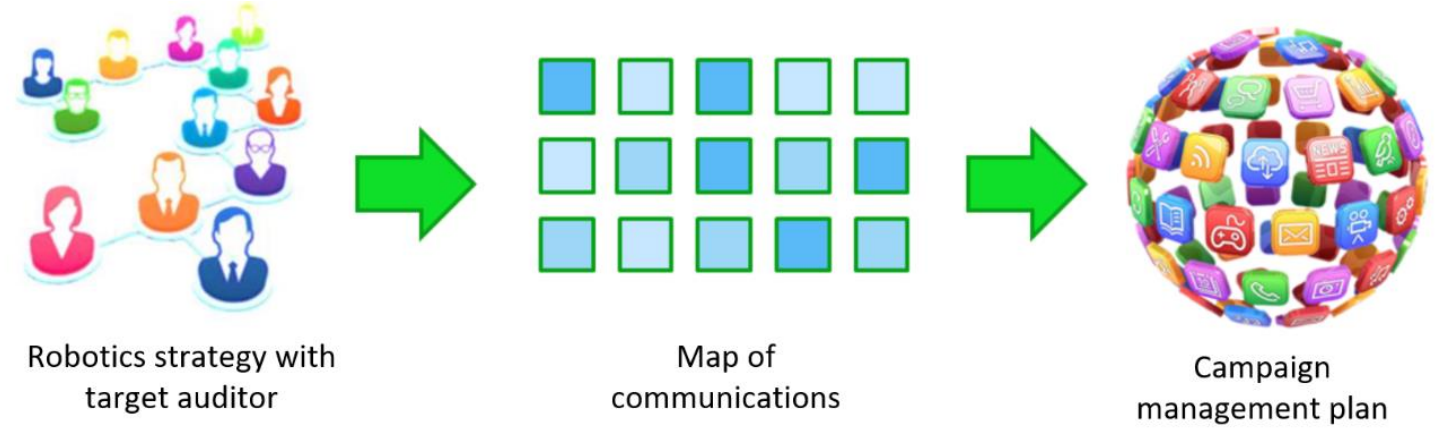

Fig. 7. Methodology for developing digital communication strategy

Each of them is a series of steps and practical recommendations that can be used to independently build a system of relationship management both within the community and between communities and various organizations and institutions to achieve specific goals.

Digital communication strategy allows you to give reasonable answers to the questions of why, to whom, when, what, where and how to tell about your organization, its activities, a new project or initiative. Based on objective data - the trends and attitudes of civil society, partners, target audience, stakeholders and more. As a rule, it is developed simultaneously with the communication strategy and covers issues related to ways of disseminating information about the organization and its activities on the Internet.

The digital communication strategy includes the following basic steps (Fig. 8). 


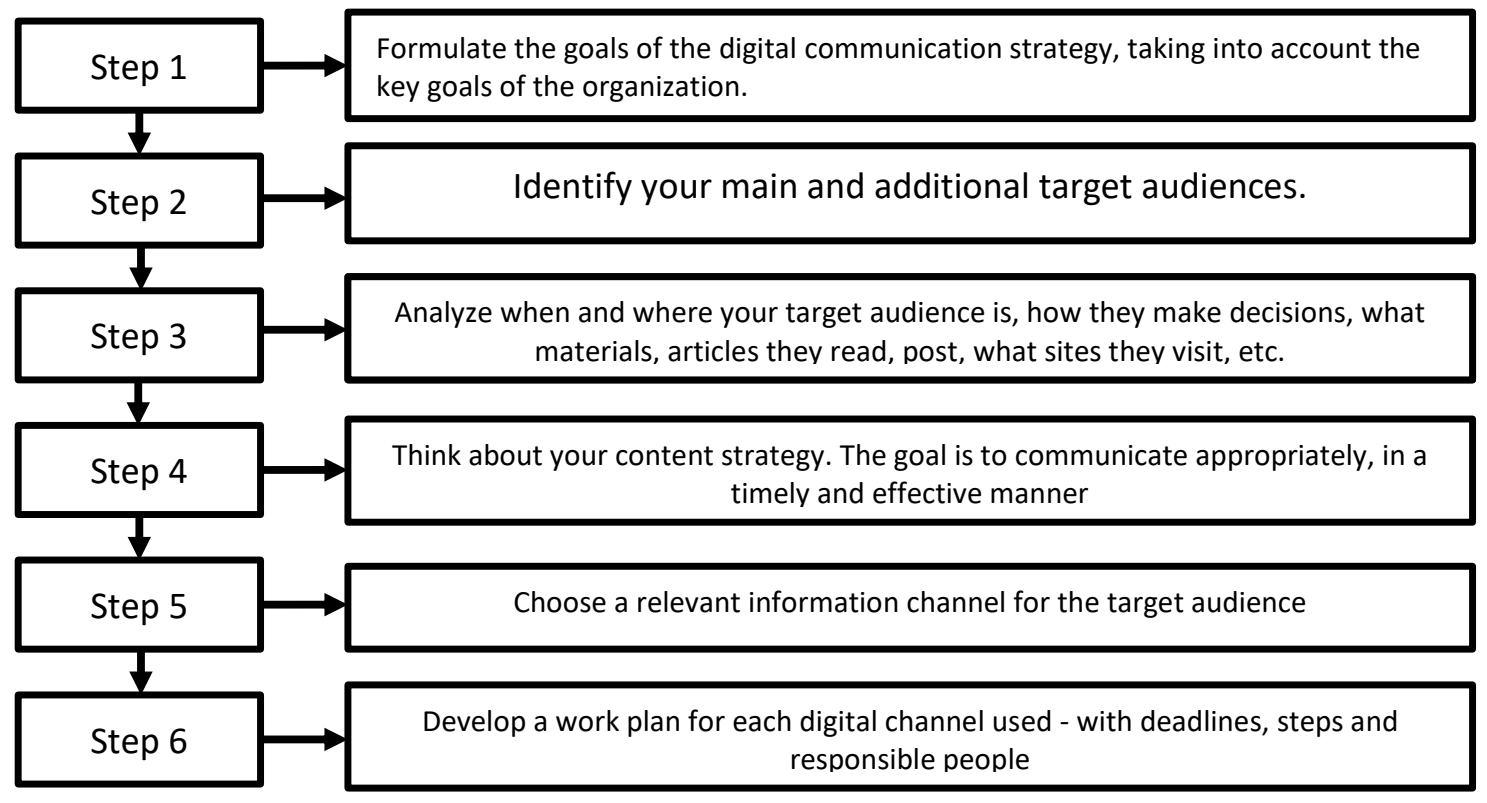

Figure 8. Stages of digital communication strategy

In order to form your own digital communication strategy you need to answer 6 simple questions:

1. WHY: who are you and why? Formulate the goals of the digital communication strategy, taking into account the key goals of the organization. Here it is important to clearly understand the purpose of the organization, values, differences from others and so on. The result of answering this question will be:

- identifying opportunities and challenges for the organization as a whole and, more specifically, where digital applications and solutions can help;

- identification of values, selection of the target audience for which this value is important and awareness of the possibility to build digital communication with him;

- analysis and prioritization of the needs of the target audience, which the organization can help solve or meet;

- identification of partners. Analysis of organizations working in the same field will give us important data for a digital communication strategy - you can make good decisions, establish effective partnerships, initiate joint flash mobs, hashtags, thematic frameworks, etc .;

- determination of own positioning. You need to take a position that will be different from others. Positioning is based on advantages - functional and emotional.

- formation of a unique value proposition, which should be clear, accurate, and short ( 5 seconds - because there is only so much time to attract and retain attention).

To determine the value of the target audience, it is necessary to make a list of all its benefits, and then reduce all the benefits to one unique value. This analysis is good to do with a command in the format of "brainstorming", you can use the following tools Padlet, Jamboard, Coggle.it, Mind42, XMind and more.

2. WHO ?: we study the target audience.The main and additional target audiences are defined. To build an effective digital communications strategy, you need to know your target audience well. It is necessary to understand: is it true that what we know about our target audience is still relevant? How has their assessment and attitude towards your organization changed, and how can we meet new expectations?

It is important to clearly understand the needs, capabilities and characteristics of each target audience. A deep understanding of the target audience will allow you to build a truly individual communication. However, the target audience cannot be "all civil society" or "all the inhabitants of a 
given community", because by communicating with everyone, we will not be able to effectively convey our message to anyone.

3. WHEN ?: understand the path of the target audience. We analyze when (at what time: morning, evening, Saturday or Wednesday, etc.) and where (in which social networks or platforms, messengers or sites, etc.) is the target audience, how it decides what materials, articles to read, post, which sites he visits, etc.

4. WHAT: what are we talking about? Quality content is the key to success. It is important to think about your content strategy, you should determine the tone, audience, method and time of content distribution. The goal is to communicate appropriately, in a timely and effective manner. There are cases when one approach or tone resonates more in one audience than in another. Each target audience needs to be addressed "in its own language." For example, Facebook highly values unique content created specifically for this social network, and therefore for successful promotion it is very important to pay attention to the quality of content, publishing something really original, authentic. What matters is not so much the frequency of posts and the number of posts, as the value for the target audience, so the preparation of content for publication on Facebook should be taken as seriously and responsibly.

The text should be structured, diverse, easy to read, interesting, have relevant illustrations and pictures. Information that has presented in a continuous stream is perceived negatively. If you have a lot to say, use a method such as storytelling to capture the reader's attention and provide him with the necessary emotion.

To be effective in social networks, you need to stand out, be clear, concise and useful. And of course, don't forget that most people are visuals, so photos, videos, infographics, animations are a must have. You can not make "one-dimensional" content for all platforms (FB, Instagram, Tik-Tok, site, messengers). Each platform requires an individual approach.

5. WHERE?: selection of promotion channels. At this stage, we choose a relevant channel for communicating information to the target audience. Analyze the external and internal digital tools and channels available to your organization, and evaluate those that are available, acceptable, but not yet used by you. Formulate goals, objectives and main challenges for each channel (website, social networks, blogs, e-mail, chatbots, mobile applications, messengers, etc.). The rules of the game often change on social networks, which means that it is worth reviewing the content strategy and not thinking that it will work for many years. Especially since this is relevant now, when most people due to quarantine restrictions spend more and more time online, in particular on social networks. This trend should also be reflected in the digital communication strategy, taking into account the moods, preferences and needs of each audience, any age group, status, etc.

6. HOW?: implementation. This is a question of implementing our strategy. What exactly do we need to do now:

- Prescribe goals and key performance indicators.

- We make a to-do letter.

- Once we have decided on the tools and their key performance indicators, we prescribe a work plan for each digital channel used - with deadlines, steps and responsible people.

And solutions for project management (task managers) can help in this, in which each employee can add their tasks and write comments that will be seen by other colleagues. The most common options: Trello, Asana, Miro, Mural, Worksection. Most of these tools can be customized to your own needs and preferences - from design to synchronization with messengers and other services.

It is important to understand the algorithm of how you will check and evaluate the results of each step and the overall success of digital communications. Analyze the results and adjust your next steps. Analysis, social media statistics, online surveys will help. Tools you can use for surveys: Polleverywhere, Kahoot, Mentimeter, Padlet, Google Forms, Sli.do, etc. With analytics, you gain insights that can be used to improve digital communications. 
Recommendations for UTCs for effective implementation of digital solutions:

- do not try to start implementing digital tools or technologies used by others without first determining what is necessary in your case. The success of the implementation of digital transformation in a public organization requires a deep understanding of stakeholders;

- Introduce and deepen digital competencies of representatives of public organizations. This requires a rethinking of functions, training of employees, perhaps it would even be useful to attract new people who will help the rest of the organization to introduce a more digital mentality and gradually adapt the global organizational culture to this new environment;

- Start digitizing all possible processes immediately. But a holistic approach to digitization should be kept in mind, including visions and priority steps, tools and methods. This process can be facilitated through cooperation, exchange of knowledge and experience, pooling of funding and partnership with other organizations, etc.;

- Effectively use social networks to promote their public organization and activities, dissemination of key messages;

- Use digital tools to communicate with such a wide audience as partners, potential partners, donors and volunteers. Keep in mind that anything you teach online can maintain or damage your reputation.

\section{Conclusion}

In this study the main aspects of implementation of digital tools of territorial communities and their role in improving the quality of services to the population are considered.

Based on the analytical study of the monitoring of the course of territorial and administrative reform of Ukraine, the systems are presentedassessments of the implementation of the idea of decentralization in the reform of the territorial-administrative system. The basic tendencies are considered, the basic laws, regions-leaders and outsiders in processes of development of the united territorial communities are allocated. The analysis uses the results of a survey to identify problematic aspects of the provision of administrative services by the united territorial communities, the results and feasibility of measures to reform the territorial and administrative system of Ukraine.

The study focuses on interaction with residents of relevant UTCs, and on the cooperation of local communities in improving the quality of services to the population. Peculiarities and main aspects of digital interaction with the residents of the territorial community and effective coverage of the government's activities with digital tools are identified. It is proposed as a mechanism of cooperation of UTC by means of digital communications to improve the quality of services to the population of territorial communities implementation of the digital communication strategy.

It is proved that UTC's ability to integrate into the European digital infrastructure is determined by the level of dissemination and the existing practice of using digital tools of interaction with UTC residents.

It is established that the purpose of local self-government reform is to ensure its ability to independently, at its own resources, to address issues of local importance. It is shown that the cooperation of UTC, based on which the tools and means of digital communications contribute to improving the quality of services to the population of local communities.

\section{References}

1. Al-Ruithe, M., Benkhelifa, E. \& Hameed, K. (2018). Key issues for embracing the cloud computing to adopt a digital transformation: A study of saudi public sector. Procedia Comput. Sci., 130, 10371043.

2. Babenko, V., Pasmor, M., Pankova, Ju., Sidorov, M. (2017). The place and perspectives of Ukraine in international integration space. Problems and Perspectives in Management, Vol. 15, Issue 1, pp. 80-92. http://dx.doi.org/10.21511/ppm.15(1).2017.08 
3. Bondarenko, S., Halachenko, O., Shmorgun, L., Volokhova, I., Khomutenko, A. \& Krainov, V. (2021). The Effectiveness of Network Systems in Providing Project Maturity of Public Management. TEM Journal, 10(1), 358-367.

4. Bondarenko, S., Laburtseva, O., Sadchenko, O., Lebedieva, V., Haidukova, O. \& Kharchenko T. (2019). Modern Lead Generation in Internet Marketing for the Development of Enterprise Potential. International Journal of Innovative Technology and Exploring Engineering, 8 (12), 30663071.

5. BONDARENKO, S., TKACH, I., DROBOTOV, S., MYSYK, A., PLUTYTSKA, K. (2021). National Resilience as a Determinant of National Security of Ukraine. Journal of Optimization in Industrial Engineering. 14 (1), Winter \& Spring. 111-117.

6. Charter for Multilevel governance in Europe. (2014). European Committee of th Regions. 20/02/2014. URL: https://portal.cor.europa.eu/mlgcharter/Pages/MLG-charter.aspx

7. E-Governance for Accountability and Participation (EGAP). URL: https://egap.in.ua/en/

8. EISING, R. (2004). Multilevel Governance and business interests in the European Union. Governance, 17(2), 215-216.

9. European Commission. eGovernment in local and regional administrations: guidance, tools and funding for implementation. URL: https://ec.europa.eu/digital-singlemarket/en/news/egovernment-local-and-regional-administrations-guidance-tools-andfundingimplementation

10.Europrean Commission. European Regional Development Fund. URL: https://cohesiondata.ec.europa.eu/funds/erdf

11.Florax, R.J.G.M., Plane, D.F. (2004). Fifty Years of Regional Science.- SpringerVerlagBerlinHeidelberg. p. 166.

12.Gontareva, I., Babenko, V., Shmatko, N., Litvinov, O., Hanna, O. (2020). The Model of Network Consulting Communication at the Early Stages of Entrepreneurship. WSEAS Transactions on Environment and Development, Vol. 16, pp. 390-396. https://doi.org/10.37394/232015.2020.16.39

13.Khomutenko, A., Mishchenko, A., Ripenko, A., Liulchak, Z. \& Hrozovskyi R. (2019). Tools of the neuro-fuzzy model of information risk management in national security. International Journal of Engineering and Advanced Technology, Volume-8 Issue-6. p. 4526-4530.

14.Malyarets, L.M., Babenko, V.O., Nazarenko, O.V., Ryzhikova, N.I. (2019). The Modeling of Multicriteria Assessment Activity in Enterprise Management, Int. J Sup. Chain. Mgt, vol. 8, no. 4, pp. 9971004. http://ojs.excelingtech.co.uk/index.php/IJSCM/article/view/3342

15.Margetts, H. (2007). Virtual Organizations: URL: https://www.oxfordhandbooks.com/view/10.1093/oxfordhb/9780199226443.001.0001/oxfordhb 9780199226443-e-14

16.Ministry and Committee for Digital Transformation of Ukraine. URL: https://thedigital.gov.ua/

17.Monitoring of decentralization (2020). URL: https://donors.decentralization.gov.ua/

18.OECD (2016), OECD Regional Outlook 2016: Productive Regions for Inclusive Societies, OECD Publishing, Paris. URL: http://dx.doi.org/10.1787/9789264260245-en

19.OECD (2018). OECDPublishing, Paris. URL: https://read.oecd-ilibrary.org/urban-rural-and-regionaldevelopment/9789264301481-uk\#page1

20.OECD Regional Outlook (2011). Building Resilient Regions for Stronger Economies.-OECD Publishing. p. 204-205.

21.Omar, A., Weerakkody, V. \& Sivarajah, U. (2017). Digitally enabled service transformation in UK public sector: A case analysis of universal credit. Int. J. Inf. Manag., 37, 350-356.

22.Peter, J., \& Robinson, P. (2014). “Civic Hackathons: Innovation, Procurement, or Civic Engagement?: Civic Hackathon: Procurement or Civic Engagement?" Review of Policy Research 31 (4):349-57. doi: 
10.1111/ropr.12074.

23.Podgorna, I., Babenko, V., Honcharenko, N., Sáez-Fernández, F. J., Fernández, J. A. S., Yakubovskiy, S. (2020). Modelling and Analysis of Socio-Economic Development of the European Union Countries through DP2 Method. WSEAS Transactions on Business and Economics, Volume 17, Art. \#44, pp. 454-466. https://doi.org/10.37394/23207.2020.17.44

24.Projects and programs. URL: https://donors.decentralization.gov.ua/

25.Rabinovych, M., Levitas, A. \& Umland A. (2018). Revisiting Decentralization After Maidan: Achievements and Challenges of Ukraine's Local Governance Reform, Kennan Cable, 34. URL: www.wilsoncenter.org/publication/kennan-cable-no-34-revisiting-decentralization-after-maidanachievements-and-challenges

26.Regions Matter (2009): Economic Recovery, Innovation and Sustainable Growth.- OECD Publishing, $110 \mathrm{p}$.

27.Rodriguez-Pose, A. \& Garcilazo, E. (2013). Quality of Government and the Returns on Investment: Examining the Impact of Cohesion Expenditure in European Regions.- OECD Regional Development Working Papers, OECD Publishing, Paris.

28.Shaikh. A. The Impact of Management of Information Communication Technology (MICT) on Society- International Conference on Communication, Management and Information TechnologyICCMIT, Vienna, Austria. Indian Journal of Science and Technology, Vol 12(18), ISI web of science.

29.Sagan, O., Yakovleva, S., Anisimova, E., Balokha, A., \& Yeremenko, H. (2020). Digital didactics as a new model in the theory of education. Revista Inclusiones, 7 num Especial, 193-204.

30.Sudomyr, S., Niziaieva, V., Lutay, L., Prodanova, L., Havryliuk, O. \& Sherstyukova K. (2020). Methods And Techniques of Motivation of Subjects Of Regional Economy For Innovative Improvement. Iternational Journal of Scientific \& Technology Research. 9(3). 1196-11200.

31.Shahzad, B., \& Crowcroft, J. (2019). Trustworthy electronic voting using adjusted blockchain technology. IEEE Access, 7, 24477-24488.

32.Tkach, I. M., Loishyn, A. A., Liashenko, I. O., Zinchenko, A. \& Lobanov, A. A. (2019). Research of main international approaches for risk management process's standardization in the context of internal control standardization in the Armed Forces of Ukraine and providing national security. Revista Espacios. Vol. 40 (Number 20) P. 14 URL:

http://www.revistaespacios.com/a19v40n20/19402014.html

33.Umland, A. (2019). Ukraine's Decentralization: Challenges and Implications of th Local Governance Reform after th Euromaidan Revolution (Stuttgart: ibidem-Verlag, 2019)

34.Weerakkody, V., Omar, A., El-Haddadeh, R. \& Al-Busaidy, M. (2016). Digitally-enabled service transformation in the public sector: The lure of institutional pressure and strategic response towards change. Gov. Inf. Q., 33, 658-668. URL:

https://www.sciencedirect.com/science/article/abs/pii/S0740624X16300934?via\%3Dihub 